\title{
The spatialization of Islamist, populist, and neo-Ottoman discourses in the Turkish capital under AKP rule
}

\author{
Husik Ghulyan
}

\begin{abstract}
This article discusses the recent politics of space in Turkey during the rule of the Justice and Development Party (Adalet ve Kalkınma Partisi, AKP) through a focus on the capital city of Ankara. In order to analyze the recent politics of space in Turkey, the article elaborates upon the recent politics of toponym changes and the discourse over space and place in the Turkish capital. Particular attention is paid to the spatialization of neo-Ottoman, Islamist, and populist discourses and to the production of various representational and counter-representational spaces. One of the key foci of the article is its elaboration on the new Presidential Complex (Cumburbaşkanliğı Külliyesi) as a case that, in its representational and conceptual aspects, reflects the spatialization of Islamist and populist discourses and symbolizes the recent transformations of social space and the emergent sociospatial order in Turkey.
\end{abstract}

Keywords: Politics of space; spatialization of discourse; Islamism; populism; neo-Ottomanism; Ankara; Turkish Presidential Palace

\section{Introduction}

The ideas that space is a social product and that the social and spatial are inseparable realms have started to receive wide acceptance in social theory since the initial proposition of and elaborations upon these issues in the late

Department of Political Sciences and Public Administration, Ankara University, Emniyet, Dogöl Cad. 6A, 06560, Yenimahalle, Ankara, Turkey; ghulyan@ankara.edu.tr, husikghulyan@gmail.com

Author's Note: This article is based on my doctoral dissertation, completed under the supervision of Prof. Tayfun Çınar in 2017 at the Graduate School of Social Sciences of Ankara University. However, substantial revisions have been made and additional comments added to support the main arguments. I would like to express my appreciation to Michelle Yeoman, Amber Murrey, Biray Kolluoğlu, and three anonymous reviewers for their valuable comments, criticism, and support. Please also note that this study received no specific grant from funding agencies in the public, commercial, or not-for-profit sectors. 
1960s. ${ }^{1}$ The initial propositions were made by Marxist scholars, mostly in the field of geography, and aimed first and foremost at a critical understanding of the problematic of space in the reproduction of capitalist social and production relations, after which came thinkers like Foucault, who elaborated upon the connections between power and space, especially how particular spatializations aimed at the functioning of power relationships. ${ }^{2}$ Now, alongside the initial conceptual and theoretical undertakings of Marxist geographers and philosophers, there is a substantial body of literature focusing on the interrelations of the social and the spatial, as well as on the thoughts and conceptualizations about space by postmodern thinkers ranging from Julia Kristeva and Gilles Deleuze to those of political thinkers and philosophers like Hannah Arendt and Jacques Rancière. ${ }^{3}$ Within the scope of that literature, it is broadly accepted that the interrelations of the social and spatial go beyond space as a "geometry," and the symbolic meaning of particular places/spaces and spatializations-including the spatialization of discourse-has a pivotal place in these interrelations, especially in those between the political and the spatial. Moreover, in such interrelations the spatial appears as not a mere dimension, but in fact as the medium of the intervention of ideology. This intervention of ideology relates not only to the (re)production of capitalist social and production relations-as suggested by the initial propositions of Marxist thinkers ${ }^{4}$ - but indeed space also constitutes a "mode of political thinking"; i.e., it is political because it makes manifest the partitionings of the established order and provides a domain of experience for the constitution of political identities. ${ }^{5}$ It is only through intervention into social space and its production and reproduction and embodiment therein that any ideology manages to achieve consistency. ${ }^{6}$ For this reason, space as both a built environment and a medium around which ideological discourse revolves appears as the ultimate locus and medium of struggle, and as a result space proves to be a crucial political issue: "[T]here is a politics of space because space is political." Thus, as the

1 Edward Soja, Postmodern Geographies: The Reassertion of Space in Critical Social Theory (London: Verso, 1989).

2 Michel Foucault, Security, Territory, Population: Lectures at the College de France 1977-1978, ed. Michel Senellart, trans. Graham Burchell (New York: Picador, 2007).

3 Russell West-Pavlov, Space in Theory: Kristeva, Foucault, Deleuze (New York: Rodopi, 2009); Mustafa Dikeç, "Space as a Mode of Political Thinking," Geoforum 43, no. 4 (2012): 669-676.

4 Henri Lefebvre, Survival of Capitalism: Reproduction of the Relations of Production, trans. Bryant Frank (New York: St. Martin's Press, 1976).

5 Dikeç, "Space as a Mode," 675.

6 Henri Lefebvre, The Production of Space, trans. Donald Nicholson-Smith (Cambridge, MA: Blackwell, 1991), 44.

7 Stuart Elden, "There Is a Politics of Space Because Space Is Political: Henri Lefebvre and the Production of Space," Radical Philosophy Review 10, no. 2 (2007), 106-107. 
propositions above imply, a fuller understanding of the politics of space and ideology in a given context requires elaboration upon the intervention of ideology into space in terms of producing the built environment and discursively transforming the space. However, the problematic of understanding the politics of space should not be limited to "mapping the outcomes of processes" or discourses, but should also aim to understand how that intervention facilitates the organization of society, since "society is necessarily constructed spatially, and that fact-the spatial organization of societymakes a difference to how it works." 8 In other words, space and the politics of space not only reflect societal relations, but at the same time space also reflects and shapes societal relations and structures. ${ }^{9}$

Due to these kinds of relationships between the social and the spatial, space has a strong political import, and as this paper will detail, this political import of space can be traced in the politics of space in post-2000 Turkey, where, in 2002, the newly established Islamist Justice and Development Party (Adalet ve Kalkınma Partisi, AKP) came to power.

In 2002, when the AKP came to power in Turkey, a transformation of social space began to occur, both as a discourse on space and as practices of the production of the built environment. It should, though, be noted that this trend has existed since the 1990s, when the Welfare Party (Refah Partisi, RP) first appeared on the political scene and took power in the major municipalities of Turkey. ${ }^{10}$ The politics of space during the RP era is a wellresearched topic. ${ }^{11}$ During RP rule, there was a transformation of urban space, both discursively and as production of the built environment: Islamic elements, discourse, and practices began to be notable in terms of street name changes, architectural motifs, and various Islamic social practices in public spaces, as has

8 Doreen Massey, "Politics and Space/Time," New Left Review 196 (1992), 70.

9 For the interrelations and causal effectivity of the social and the spatial, see Edward Soja, "The SocioSpatial Dialectic," Annals of the Association of American Geographers 70, no 2 (1980): 207-225; Soja, Postmodern Geographies; Doreen Massey, Spatial Divisions of Labour: Social Structures and the Geography of Production (London: Macmillan, 1995); Derek Gregory and John Urry, eds., Social Relations and Spatial Structures (London: Macmillan, 1985).

10 In 1998, the RP was shut down by a decision of the Constitutional Court for violating the constitution, according to which all parties must respect the principles of Turkish secularism. The Virtue Party (Fazilet Partisi, FP), established in 1997, became the RP's successor, but in 2001 the Constitutional Court shut it down as well, as, according to the court, the party had become a focus of anti-secular activities. See Chris Morris, "Despatches," BBC News, January 16, 1998, http://news.bbc.co.uk/2/hi/ middle_east/48001.stm; "Turkey Bans Islamic Party," BBC News, June 22, 2001, http://news.bbc.co. uk/2/hi/europe/1402927.stm.

11 Ülkü Doğanay, "Türkiye'de Siyasal İslam ve Kentsel Mekânlar: Fazilet (Refah) Partili Büyükşehir Belediyesi'nin Ankara'daki Uygulamaları," Çağdaş Yerel Yönetimler Dergisi 9, no. 1 (1999): 3-19; Miray Özkan and Ali Cenap Yoloğlu, "Bir Bellek Projesi Olarak Sokak İsimlendirmesi: Ankara Örneği," Planlama 2005/4 (2005): 54-60. 
been examined by a large body of literature. ${ }^{12}$ Due to the rise of political Islam in local and national politics, after 1990 the social space in Turkey developed important representational aspects in this respect, on all scales. One of the turning points in this process was the replacement of the city emblem of Ankara, the capital of secular Turkey, with a new one bearing explicitly Islamic motifs. The older emblem-which represented the ancient Hittite civilization of Anatolia and acted as a representation of the space and history of Kemalist ideology ${ }^{13}$ — was replaced by an emblem depicting a large mosque, a clear representation of Islamist ideology. ${ }^{14}$

It is also worth mentioning the significance Ankara held in the national space and history of Turkey during this period when Islamic representational aspects of space began to gain importance. Ankara served as the representation of the space of the secular republic, with both its representational spaces and its spatial practices being synonymous with the Kemalist modernization project of Turkey. It was due precisely to these particular representational

12 Bülent Batuman, "Mekân, Kimlik ve Sosyal Çatışma: Cumhuriyet'in Kamusal Mekânı Olarak Kızılay Meydanı," in Ankara'nın Kamusal Yüzleri: Başkent Üzerine Mekân-Politik Tezler, ed. Güven Sargın (İstanbul: Illetişim, 2002): 41-76; Alev Çınar, Modernity, Islam, and Secularism in Turkey: Bodies, Places, and Time (Minneapolis: University of Minnesota Press, 2005); Alev Çınar, "The Imagined Community as Urban Reality: The Making of Ankara," in Urban Imaginaries Locating the Modern City, ed. Alev Çınar and Thomas Bender (Minneapolis: University of Minnesota Press, 2007): 151-81; Ali Ekber Doğan, "Gökçek'in Ankara'yı Neo-Liberal Rövanşçılıkla Yeniden Kuruşu," Planlama 2005/4 (2005): 130-38; Ali Ekber Doğan, Eğreti Kamusallık: Kayseri Örneğinde İslama Belediyecilik (İstanbul: Illetişim, 2007); Doğanay, "Türkiye'de Siyasal İslam"; Özkan and Yoloğlu, "Bir Bellek Projesi"; Güven Arif Sargın, "Displaced Memories, or the Architecture of Forgetting and Remembrance," Environment and Planning D: Society and Space 22, no. 5 (2004): 659-80; Güven Arif Sargın, "Sincan, a Town on the Verge of Civic Breakdown: The Spatialization of Identity Politics and Resistance," in Visualizing Secularism and Religion: Egypt, Lebanon, Turkey, India, ed. Alev Çınar, Srirupa Roy, and Maha Yahya (Ann Arbor: The University of Michigan Press, 2012): 258-80; Gizem Zencirci, "Secularism, Islam, and the National Public Sphere: Politics of Commemorative Practices in Turkey," in Visualizing Secularism and Religion: Egypt, Lebanon, Turkey, India, ed. Alev Çınar, Srirupa Roy, and Maha Yahya (Ann Arbor: The University of Michigan Press, 2012): 93-109.

13 After the establishment of the Republic of Turkey in 1923, the major step toward nation-state building was the rejection of the Ottoman past by the Kemalist regime, and to this end the construction of a new representation of space and history, according to which the actual roots of the new social formation were to be found in the ancient civilizations of Anatolia, such as the Hittites. For a detailed account of these processes and the spatio-historical conception of the nation in Turkey during the 1923-1950 period, see Sezgi Durgun, Memalik-i Şahane'den Vatan'a (İstanbul: İletişim, 2011).

14 While the discourse revolving around this issue in the media and politics was dominated by an emphasis on the Islamic character of the new emblem and how it was contested by secularists, even in academic discourse related to the matter the ideological connotations of the previous emblem were rarely discussed. This implicitly made it seem as if the older emblem was a neutral representation and image of Ankara, when in fact it also had clear ideological connotations, since, as Bozdoğan and Akcan have noted, the emblem representing the Hittites was rooted in the Kemalist nationalism of the 1930s. See Sibel Bozdoğan and Esra Akcan, Turkey: Modern Architectures in History (London: Reaktion Books, 2013), 218. 
aspects that Ankara came to experience a transformation with the rise of political Islam. ${ }^{15}$

Another axis of the politics of space was the transformation of various city squares and parks and road junctures with sculptures and landscape designs displaying traditional and Seljuk/Ottoman motifs. ${ }^{16}$ Furthermore, starting in 1994, there was an intense process of redenomination of Ankara's urban toponyms. ${ }^{17}$ During this process, toponyms reflecting the city's modern identity were renamed with toponyms referencing the Ottoman past and Islamic identity. ${ }^{18}$ Although references to the Seljuk and Ottoman past had begun to emerge in the 1990s, references to Islam became more dominant in this period, and it has only been in the post-2000 period that, in addition to strong references to Islam in the production of social space and the discourse over space, references to the Seljuk and Ottoman past started to dominate. ${ }^{19}$ In respect to

15 In this respect, one detail specific to Ankara highlighted by Doğan is interesting. According to Doğan, during the 1994-1998 period in the transformation of Ankara, the political figure of the mayor of Ankara is especially important. During the neoliberal transformations occurring in Ankara in the 1990s, rather than being part of the Islamic block and a doctrinal Islamist seeking revenge against the secular order, Melih Gökçek in fact supported the policies of these transformations due to his farright political disposition, since Ankara had a particularly interesting history of urban development and municipalism: on the one hand, during the early years of the republic, the capital Ankara was planned as a showcase of the modern republic, while on the other hand, during the 1970s, there was a newly developing democratic municipalism movement and practice in place in Ankara, two aspects that were both quite the opposite of Gökçek's own far-right tendencies. See Doğan, "Gökçek'in Ankara'yı," 137.

16 For a detailed account, see Doğan, "Gökçek'in Ankara'yı"; Doğanay, "Türkiye'de Siyasal İslam."

17 Özkan and Yoloğlu, "Bir Bellek Projesi."

18 Ibid.

19 As Doğanay shows, since 1994 - when the Ankara Metropolitan Municipality was under the control of the RP and the FP-there have been several noticeable attempts by the municipality to reshape the built environment of the city through elements associated with traditional Ottoman and Islamic architecture, such as fountains, pools, domes, and arches. Such elements, in combination with the elements of modern architecture and advanced technology, were thought to emphasize the Islamic roots and identity of Ankara. Regarding the spatial practices of the period, Batuman, in elaborating on the public spaces of the city under the RP, points to the Islamist populism of the municipality that aimed at reshaping the use of public space according to Islamist ideology and spreading it widely among the mass of the population. See Doğanay, "Türkiye'de Siyasal İslam"; Batuman, "Mekân, Kimlik ve Sosyal Çatışma." Thus, although Ottoman elements began to appear in the built environment of the city during this period, it was actually in the post-2002 period when, along with strong references to Islam in the production of social space, references to the Seljuk and Ottoman past started to become more dominant. As the most pertinent examples of such a change we can note the five SeljukOttoman style entrance gates of the city and the restoration and renovation of two old neighborhoods (Hammamönü and Hacıbayram). In this regard, another interesting example was the transformation of Ankaraspor FC (a soccer team that previously functioned as a sporting club of the municipality) into Osmanlispor (i.e., "Ottoman Sporting") and the changing of the club's logo to one with clear Ottoman connotations. This last example may not be related to the politics of space, but it is important in terms of the representation of the city by means of a soccer team. All of the aforementioned changes have taken place over the last decade, and all of them could easily be read as attempts to highlight the Ottoman past of the capital city. Thus, while the 1990s do indeed appear 
these recent toponym changes in Ankara, the cases of university campuses and the new presidential palace appear as especially interesting examples of the spatialization of Islamist and neo-Ottoman discourses in the Turkish capital. During the last few years, the building of new, pseudo-Islamic külliye complexes and the redefinition of various social spaces bear implications for understanding the production of social space and the emerging novel sociospatial order in Turkey. Moreover, in the case of both the toponymic changes in Ankara and discussions centered around the new presidential palace, it is also possible to speak of a spatialization of populist discourse, which has been a persistent element of the AKP's rhetoric. ${ }^{20}$

This article will evaluate the recent discourse over space in Turkey during AKP rule by focusing on several major cases in the capital of Ankara. These cases are as follows: the first is the toponym changes, where, along with general toponymic trends, several key examples will be discussed in greater detail; the

to have signaled the start of such changes as Islamist parties took power at the local level, it was only after 2000, when the AKP took power at both the local and the national level, that all of these sorts of changes became more systematic and visible and began to stress both Islam and the Seljuk and Ottoman past.

20 According to Yaşlı, for many years in Turkey the basic paradigm of the social sciences has been a reading of recent Turkish history according to which there is an alienated order on the one side consisting of centrists, pro-Westerners, and supporters of guardianship and tutelage, while on the other side there are the pious popular masses (the people/nation or millet) and their political representatives, which are mainly the center-right parties. Yaşlı points out that, under the rule of the AKP, the paradigm has taken the following state: the Kemalist regime continued uninterrupted for 80 years; this alienated regime of guardianship and tutelage pulled Turkey away from the Islamic civilization to which it properly belongs and tried to attach it to Western civilization; as a result, there has been an attempt to impose non-national values on the nation, with persecution being severe and the state ceasing to be national. See Fatih Yaşlı, AKP, Cemaat, Sünni-Ulus: Yeni Türkiye Üzerine Tezler (İstanbul: Yordam Kitap, 2015), 130-131. Similarly, Koyuncu, in elaborating upon this reading and representation of recent Turkish history, notes that the populist rhetoric used by the AKPwhich rewrites recent national history so as to depict a state composed of commoners who are the true masters of the nation on the one side and those who do not want commoners to develop and who indeed humiliate the commoners on the other side-presents the AKP as the true representative of commoners and the only force that struggles against those who would humiliate them. See Büke Koyuncu, "Benim Milletim .. .": AK Parti Iktidarı, Din ve Ulusal Kimlik (İstanbul: İletişim, 2014), 175. Within the framework of this article, I would accede to Yaşlı and Koyuncu's views as shorthand descriptions of how the AKP has positioned itself in contemporary Turkish political history, and furthermore elaborate on the spatializations of such a populist narrative. Moreover, for the definition of Islamism, I take Göle's definition of Islamism, as a reappropriation of a Muslim identity and values for a particular social and political agenda. See Nilüfer Göle, "Secularism and Islamism in Turkey: The Making of Elites and Counter-Elites," Middle East Journal 51, no. 1 (1997): 46-58. Based on such a definition, the spatialization of Islamism is a spatial politics aimed at a redefinition of social space according to a Muslim identity and Muslim values. Such a redefinition can involve not only the physical transformation of social space according to Islamic values, symbols, architecture, and spatial practices pertaining to the everyday practice of the religion, but also a discursive redefinition of space as well. At the same time, by the spatialization of neo-Ottomanism I imply a production of the built environment and a discursive redefinition of space that take as their main reference point elements of the Seljuk/Ottoman past and historiography. 
second involves the recent discussions centering around university campuses; and the third is the recent discursive and building practices of külliye complexes, particularly the new presidential palace. Through examination of these cases, the article will expose the spatial aspects and spatialization of Islamist, populist, and neo-Ottoman discourses in the Turkish capital. Moreover, in the subsequent discussion analyzing the politics of space of the AKP, the aim will be not only to trace the spatializations of specific discourses and the outcomes of the politics of the spaces involved (as the very notion of "spatialization" implies), but also to reflect upon the issue of what those spatializations reveal regarding the emerging sociospatial order in Turkey.

\section{Redefining representational spaces through toponym changes}

As noted above, during the 1990s there was an intense process of (re)denomination of urban toponyms in Ankara, ${ }^{21}$ according to which toponyms reflecting Ankara's modern identity were replaced with toponyms referencing the Ottoman past and Islamic identity. My analysis has shown that this trend has continued in the post-2000 period as well. For example, my analysis of 301 renamings of urban toponyms (streets, boulevards, etc.) for the 20132015 period reveals that, among these changes, ${ }^{22}$ approximately 23 percent of the new toponyms referred in various ways to Seljuk/Ottoman historiography - the main historical reference point for the ruling AKP—or to Islam. Among the changes, the most frequent type were those that made reference to specific personalities in Seljuk and Ottoman historiography and Islamic thought. ${ }^{23}$ Although the analysis covers a very short period and so cannot serve as the basis for assertive conclusions, the fact that approximately 23 percent of total toponym replacements refer directly to Islam and Seljuk/Ottoman historiography is quite consistent with the neo-Ottoman and Islamist aspirations of the ruling AKP. As such, this variety of spatial politics throughout the Ankara Metropolitan Municipality reflects the aspirations of the ruling

21 Özkan and Yoloğlu, "Bir Bellek Projesi."

22 For the complete list of these replacements, see "Değişen Cadde ve Sokak Isimleri," Ankara Büyükşehir Belediyesi, https://www.ankara.bel.tr/genel-sekreter-yardimcisi-vedat-ucpinar/fen-isleridairesi-baskanligi/numarataj-sube-mudurlugu/degisen-cadde-ve-sokak-simleri.

23 Among the new toponyms referring to Seljuk and Ottoman history are the names of Malik-Shah I, Aruj Barbarossa (Oruç Reis), Occhiali, Salah Rais, Seydi Ali Reis, Çandarlı Halil Pasha, and others. Among the new toponyms referring to various Islamic scholars are the names of Akshamsaddin, Abdullah Faruki, Alaaddin Fersafi, Mustafa Asım Köksal, Aziz Mahmud Hudayi, Tapduk Emre, al-Ghazali, and others. There are also toponyms referring directly to Islam, such as Ahl al-Bayt, Safahat, Hafiz, Hejaz, Badr, Ihvan, Kandil, Nisa (an-Nisa), etc. 
AKP to change the representational spaces of Ankara; ${ }^{24}$ namely, it appears to be a discursive redefinition of space by the ruling power according to the historical narratives (Seljuk/Ottoman historiography) and within the ideological framework (Islamism) from which that power embarks. At least initially, these changes could not be considered deliberate and intentional redefinitions of representational aspects of urban social space simply because some portion of the renamings were in accordance with a particular historiographical discourse or ideological conception of history and politics. During the period under discussion, however, when the AKP initiated toponymic changes for certain important public spaces in the capital (squares, boulevards, etc.), those attempts as well as the discussions revolving around them show that the changes indeed were deliberate redefinitions of representational spaces in Ankara.

Over a four-month period in 2013, the Ankara Metropolitan Municipality constructed a boulevard that was, at the time, called the METU Road since it intersected part of the campus of Middle East Technical University (METU; Orta Doğu Teknik Üniversitesi), connecting the Eskişehir Road and Anadolu Boulevard to the Konya Road. After construction was completed, the municipality's council decided to rename the road "1071 Malazgirt Boulevard." 5 This case is a particularly interesting one in terms of reflecting the representational redefinition of urban social space. The renaming of the boulevard was accepted unanimously by the council, ${ }^{26}$ notwithstanding the reaction from certain parts of society against the new name and following serious discussions in the media. ${ }^{27}$ The reaction of various social groups to the road's renaming could be read as a reaction to the redefinition of the representational aspects of urban

24 The notion of representational space (lived space) refers to the "space which the imagination seeks to change and appropriate. It overlays physical space, making symbolic use of its objects." Thus, toponyms closely relate to representational space because toponyms, especially rooted ones, belong to the mental aspect of the social space and are before all else lived by inhabitants mentally, which is one of the reasons why Lefebvre also defines representational space as lived space. See Lefebvre, The Production of Space, 39.

25 Malazgirt (Manzikert) is the place in Anatolia where, on August 26, 1071, the Battle of Manzikert was fought between the Byzantine Empire and the Seljuk Empire, resulting in a Byzantine defeat and ultimately leading to the Turkification of Anatolia.

26 Ahmet Köprülü, “ODTÜ Yolu'na, '1071 Malazgirt Bulvarı' Adı Verildi," Büyükşehir Ankara 10, no. 469 (2014): 16-17.

27 Uğur Yıldırım, "Malazgirt Atışması," Sabah, February 19, 2014, http://www.sabah.com.tr/ankarabaskent/2014/02/19/malazgirt-atismasi. Among the discussions, a tweet by the journalist Can Dündar reveals another representational aspect of the issue: "Turks entered into Anatolia in 1071. The Byzantine army was massacred by a sword. And today the 'METU Road,' the result of massacre by axe, was renamed the 'Malazgirt Road'." Can Dündar, Twitter post, February 15, 2014, https:// twitter.com/candundaradasi/status/434785308400291840. During construction of the new road, some parts of the forest belonging to the campus of Middle East Technical University were cut down. In this regard, Dündar's tweet shows the representational aspect of the issue related to the destruction of a natural milieu for the sake of traffic flow. Dündar's reaction reflected the negative stance of environmentally concerned groups, who contested the construction of the boulevard. 
social space by the ruling power, a redefinition that, within the urban social space, aims to make that power's own chosen historiographical narratives the dominant ones. In connection with the road's new name, the mayor of Ankara at the time, Melih Gökçek, stated that, "we found this name appropriate in order to remind [people about] the entrance date of the Turks into Anatolia." 28 Thus, since the new boulevard is the continuation of Anadolu (i.e., Anatolia) Boulevard, and the Turks' arrival into Anatolia is traditionally ascribed to the Battle of Manzikert (i.e., Malazgirt) in the year 1071, such a name was especially meaningful. ${ }^{29}$

Naming the boulevard "1071 Malazgirt" was an attempt to produce a representational space symbolizing the Turkish advent in Anatolia, an extremely prominent event in Seljuk historiography; thus, it could be read as the ideologically motivated production of a representational space according to the Seljuk-Ottoman aspirations of the AKP. At the same time, it could also be considered an example of populist nationalism aimed at the wider society; in this regard, the unanimous nature of the council's renaming decision was not a coincidence. The council named a newly constructed space, rather than renaming an existing space; thus, the act of naming did not involve a serious dispute revolving around representational and counter-representational spaces between various political stakeholders, which in this case would be, first and foremost, between the Republican People's Party (Cumburiyet Halk Partisi, $\mathrm{CHP}$ ) and the AKP. Furthermore, because the name symbolizes the entrance of the Turks into Anatolia, the CHP also supported the AKP in this matter, regardless of the fact that the attempt pertained not only to Turkish identity, but also to the AKP's Seljuk-Ottoman aspirations. In fact, during the same period in Ankara, when a change of name for one of the city's important squares, Tandoğan Square, was under discussion, one witnesses an interesting attempt by the ruling power to impose its own narrative of national history and produce a representational space proper to that narrative. Here, one can see the spatialization of another variety of rhetoric proper to the AKP.

On April 13, 2015, per a motion proposed by the members of the council of the Ankara Metropolitan Municipality (representing the AKP), the name of Tandoğan Square (Tandoğan Meydanı) ${ }^{30}$ was changed to Anadolu Square

28 Yıldırım, "Malazgirt Atışması."

29 Köprülü, "ODTÜ Yolu'na, '1071 Malazgirt Bulvarı' Adı Verildi," 17. There are eight pedestrian bridges crossing the boulevard, six of which reflect the Seljuk/Ottoman historical narrative; namely, the Sultan Alp Arslan Bridge, the Sultan Alp Arslan Underpass, the Kayqubad I Bridge, the Kilij Arslan II Bridge, the Kaykhusraw I Bridge, and the Malik-Shah I Bridge. See Ankara Büyükşehir Belediyesi, "1071 Malazgirt Bulvarı'na Muhteşem Açılış," Büyükşehir Ankara 10, no. 470 (2014), 8.

30 Tandoğan Square is named after Nevzat Tandoğan, the first governor of Ankara province and simultaneously the mayor of Ankara. He served in both positions for 17 years (1929-1946) during the oneparty era when Turkey was under Kemalist rule. 
(Anadolu Meydani). ${ }^{31}$ The discussions revolving around this motion, as well as the voting by various political parties in the municipal council, are revelatory of certain important aspects in regard to the struggle over various representational spaces. During the hearings at the municipal council, members representing the CHP voted against the motion; representatives of the Nationalist Movement Party (Milliyetçi Hareket Partisi, MHP) abstained; and members of the AKP, with the votes of three independent members and one member (İbrahim Uyar) representing the Great Unity Party (Büyük Birlik Partisi, BBP), obtained the necessary two-thirds majority needed to rename the square. Uyar, in making a statement in favor of the square's renaming, noted that Nevzat Tandoğan, for whom the square was named, had insulted the people of Anatolia by calling them "louts" (öküz); in this way, Uyar implicitly expressed his reasoning for renaming the square. ${ }^{32}$

The issue of the renaming of Tandoğan Square had also been on the agenda in 2012. At that time, an independent member of the council, Hüseyin Günay, noted that Tandoğan had served as a governor and mayor of Ankara for 18 years, which had been the initial reason for the square's being named Nevzat Tandoğan Square, but he also expressed the justification for the square's renaming by stating that, during his period of service, Tandoğan had considered the people of Anatolia second-class citizens, and therefore, "the existence of such a name in the capital city of a country struggling for democracy is inappropriate, for the sake of humanity." ${ }^{33}$ In addition, according to Günay, considering also that the prominent Turkish musician and poet Aşık Veysel had been banned from entering Ankara because his appearance and dress did not conform to the dress code enforced by Tandoğan, ${ }^{34}$ Günay proposed renaming Tandoğan Square as "Independence, Republic, and

31 Tansel Semerci, “Tandoğan Meydanı, 'Anadolu Meydanı' Oldu," Büyükşehir Ankara 11, no. 528 (2015): 28-29.

32 For the discussion at the municipal council and the relevant statements, see "Tandoğan Meydanı'nın İsmi 'Anadolu Meydanı' Olarak Değiştirildi," CNN Türk, April 13, 2015, http://www.cnnturk.com/haber/ turkiye/tandogan-meydani-nin-ismi-anadolu-meydani-olarak-degistirildi.

33 See "Tandoğan Meydanı́nın İsminin Değişmesi İçin Teklif," Hürriyet, April 18, 2012, http://www. hurriyet.com.tr/tandogan-meydaninin-isminin-degismesi-icin-teklif-20369695.

34 A strict dress code was enforced in Ankara during the period of service of Nevzat Tandoğan, which had an important effect on the lived experience and spatial practices of local residents. The dress code was part of the modernization policies that were in place during the Kemalist period and was related specifically to the Kemalists' representation of space, which aimed to create a modern urban experience. The enforcement of this dress code in Ankara was of critical importance to the Kemalists because Ankara was the capital of a new republic with modern and secular aspirations and goals. Thus, according to the dress code, people without ties and workers or people from the countryside wearing coveralls or traditional garments were banned from entering the central district of the city. For a detailed account of such practices and the effect they had on the everyday experience of locals, see Funda Şenol Cantek, "Yaban"lar ve Yerliler: Başkent Olma Sürecinde Ankara (İstanbul: İletişim, 2003), 218-224. 
Democracy Square." Notwithstanding, in 2012, it was decided that instead of completely renaming Nevzat Tandoğan Square, the "Nevzat" would be dropped so that the name would simply be "Tandoğan Square," with the reasoning being that citizens would not directly relate Tandoğan Square to Nevzat Tandoğan's personality, and so the name "Tandoğan Square" would not be a direct commemoration of Nevzat Tandoğan, thereby avoiding irrelevant disputes. ${ }^{35}$

In general, the ruling AKP's initiative to rename the square, and all the disputes surrounding this renaming, could be considered consistent with the party's populist stance. An emphasis on its "being one of the people" (balktan olma) has been continuously emphasized by the AKP in both political polemics and in its own conception of national history, and this narrative is indeed considered one of the cornerstones of the populist rhetoric advanced by the AKP. ${ }^{36}$

In the discussions revolving around the renaming of Tandoğan Square, one sees the same populist rhetoric in action. Specifically, as a justification for renaming, Nevzat Tandoğan is presented as a figure who served as both the governor of Ankara province and the mayor of the city of Ankara for 17 years. During his period of service, he refused people entrance into Ankara based on their dress, and he considered the people of Anatolia to be second-class citizens, as evidenced by his calling them "louts." Thus, commemorating his name in a public space was not considered proper "for the sake of democracy and humanity." 37 This kind of rhetoric perfectly aligns with Koyuncu's comments about how the AKP presents itself as "representative of commoners" while Kemalists are presented as "humiliating commoners," and it reproduces the aforementioned populist rhetoric of the AKP. In this case, however, the discourse revolves around a particular place and aims to produce a different representational space. In this discourse, Tandoğan Square as a space/place is represented as a symbol of those who "humiliate commoners," and thus the purpose of the renaming is to suppress that particular representational aspect of the square, with the underlying reason for renaming it as "Anadolu" (Anatolia) being the production of a counterrepresentational space aligned against those who "humiliated" the ordinary

35 See "Tandoğan Meydanı'nın İsminin Değişmesi Için Teklif," Hürriyet, April 18, 2012, http://www.hurriyet. com.tr/tandogan-meydaninin-isminin-degismesi-icin-teklif-20369695; “Tandoğan Meydanı́nın İsmi Değişti," Radikal, May 14, 2012, http://www.radikal.com.tr/turkiye/tandogan-meydaninin-ismi-degisti$1088027 /$.

36 For more on this, see footnote 20 of the present article. For a detailed account, see also Koyuncu, "Benim Milletim ...," 175; Yaşlı, AKP, Cemaat, Sünni-Ulus, 131.

37 See "Tandoğan Meydanı́nın İsminin Değişmesi Için Teklif," Hürriyet, April 18, 2012, http://www.hurriyet. com.tr/tandogan-meydaninin-isminin-degismesi-icin-teklif-20369695; “Tandoğan Meydanı'nın İsmi 'Anadolu Meydanı' Olarak Değiştirildi," CNN Türk, April 13, 2015, http://www.cnnturk.com/haber/ turkiye/tandogan-meydani-nin-ismi-anadolu-meydani-olarak-degistirildi. 
people of Anatolia by calling them "louts." In short, by renaming the square as "Anadolu Square," the aim was the production of a counter-representation, and in this attempt the square appears as a counter-representational space of populist power. ${ }^{38}$

When the AKP was faced with massive waves of demonstrations from nationalist and secular political groups and citizens in the cities of Ankara, İstanbul, and İzmir in 2007-known as the "Republic Demonstrations" (Cumburiyet Mitingleri) — the first and largest demonstration in terms of participation took place at Tandoğan Square on April 14, 2007. ${ }^{39}$ Hence, the square as a representational space was not limited by the specific personality of Nevzat Tandoğan and the early periods of the Republic of Turkey (i.e., the Kemalist era). At the same time, via particular spatial practices, the representational aspect of this space came to be reproduced during that demonstration. Moreover, because the demonstration was essentially a show of force by people and political stakeholders with nationalist and secular sentiments against the Islamist $\mathrm{AKP}^{40}$ — which according to them was undermining the secular foundations of the republic - by taking this representational aspect of the square

38 According to Koyuncu, this kind of populist rhetoric used by the AKP, while assuring the necessary legitimacy for the party's policies in various matters, simultaneously also forms a protective shield for the AKP against its opponents; see Koyuncu, "Benim Milletim ...," 175. During the discussions in the council of the Ankara Metropolitan Municipality on the matter, one can observe relevant support for Koyuncu's assertion. Addressing the MHP members of the council who had abstained from participation in the voting, the mayor, Melih Gökçek, noted the following: "The representatives of the CHP are against the proposal for ideological reasons; I understand their stance. But I cannot understand the reasoning of the representatives of the MHP who are against the proposal. On television, I will announce that the MHP was against the renaming of Tandoğan Square." As a result of this statement, the MHP members stated that they were not against the proposal, but rather wanted to postpone it until after the upcoming elections, at which point they could ask the public's opinion on the matter. See “Tandoğan Meydanı́nın İsmi 'Anadolu Meydanı' Olarak Değiştirildi," CNN Türk, April 13, 2015, http://www.cnnturk.com/haber/turkiye/tandogan-meydani-nin-ismi-anadolu-meydani-olarakdegistirildi.

39 Cenk Saraçoğlu and Melih Yeşilbağ, "AKP Döneminde Türkiye: Minare Ille İnşaat Gölgesinde," in Osmanlı'dan Günümüze Türkiye'de Siyasal Hayat, ed. Gökhan Atılgan, Cenk Saraçoğlu, and Ateş Uslu (İstanbul: Yordam Kitap, 2015), 923.

40 Ibid., 923. On April 15, 2007, the banner headline of the front-page story in Hürriyet, one of Turkey's top print-news outlets, was, "The Strongest Objection" ("En Güçlü Itiraz"), and the story about the demonstration was covered over three full pages. It was described as "a demonstration that brought together people from all over Turkey, from ordinary citizens and artists to politicians, and was transformed into a show of force." The slogans chanted at the demonstration included: "Claim your republic!" ("Cumhuriyetine sahip çı"), "We're the soldiers of Mustafa Kemal" ("Mustafa Kemal'in askerleriyiz"), "Happy is he who says 'I am a Turk"' ("Ne mutlu Türküm diyene"), and "Turkey is secular and will remain secular" "Türkiye laiktir, laik kalacak"). These slogans reflect the secular and nationalist nature of the demonstration. See "\% 65'in Yüzbinleri," Hürriyet, April 15, 2007, http://www.hurriyet.com.tr/ gundem/65-in-yuzbinleri-6335051; "Ankara'da Laiklik Yanlısı Gösteri", BBC Turkish, April 14, 2007, http://www.bbc.co.uk/turkish/news/story/2007/04/070414_turkey_rally_update.shtml. 
into account, its renaming could also be read as an attempt by the AKP to suppress this representational aspect of the square as well.

Cases of redefinition of the representational aspects of social space and discussions and disputes revolving around the relevant issues are not limited to the above examples. Among the other examples that might be considered within the same framework are the discussions revolving around naming the square in front of the Ankara Central Railway Station "Peace Square" (Barı̧ Meydanı). On October 10, 2015, the "Labor, Peace, and Democracy" rally-organized by the Confederation of Progressive Trade Unions of Turkey (Türkiye Devrimci İş̧i Sendikaları Konfederasyonu, DISK), the Union of Chambers of Turkish Engineers and Architects (Türk Mühendis ve Mimar Odaları Birliği, TMMOB), the Peoples' Democratic Party (Halklarin Demokratik Partisi, HDP), the Turkish Medical Association (Türk Tabipleri Birliği, TTB), and the Confederation of Public Workers' Unions (Kamu Emekçileri Sendikaları Konfederasyonu, KESK) - took place in the square to protest escalating conflict between the Turkish armed forces and the Kurdistan Workers' Party (Partiya Karkerên Kurdistanê, PKK). ${ }^{41}$ The rally became a target for a terrorist attack, ultimately the deadliest terror attack in the history of Turkey. ${ }^{42}$ After the attack, it was proposed that the square be renamed "Peace Square," but the Ankara Metropolitan Municipality rejected the proposal and instead renamed it "Democracy Square," resulting in a dispute over the issue. ${ }^{43}$ Similarly, after the attempted coup of July 15, 2016, the central square of Ankara, Kizllay Square (Kızılay Meydanı), was officially renamed "July 15 Kizılay National Will Square" (15 Temmuz Kizilay Milli İade Meydani), which also became a matter of dispute. ${ }^{44}$ While some of the above examples were bound to certain very particular political conjunctures, others appeared in the context of narratives bound to certain personalities or events.

However, in the overall period under discussion, the more pertinent trend is the redefinition of social space not through narratives, but rather through

41 "Ankara'daki Barış Mitingini Kim Düzenledi ve Kimler Katıld?" Sözcü, October 10, 2015, http://www. sozcu.com.tr/2015/gunun-icinden/ankaradaki-baris-mitingini-kim-duzenledi-ve-kimler-katildi956109/.

42 "Ankara Explosions Leave Almost 100 Dead," BBC News, October 10, 2015, http://www.bbc.com/ news/world-europe-34495161.

43 "AKP'ye 'Barış' Fazla Geldi: Gar Meydanı́nın Adı 'Demokrasi Meydanı' Olarak Değiştirildi," Diken, October 15, 2015, http://www.diken.com.tr/akpye-baris-fazla-geldi-gar-meydaninin-adi-demokrasimeydani-olarak-degistirildi/; Mert Gökhan Koç, "Gar Meydanı Demokrasi Meydanı Oldu," Hürriyet, October 15, 2015, http://www.hurriyet.com.tr/gar-meydani-demokrasi-meydani-oldu-30323097.

44 Bahar Bayhan, "Kızılay Meydanı́nın Adının Değiştirilmesiyle illgili Mimarlar Odası'ndan Açıklama," Arkitera, July 27, 2016, http://www.arkitera.com/haber/27289/kizilay-meydaninin-adinin-degistirilmesikarariyle-ilg; "Kızılay Meydanı́na Dokunma, Parsel Parsel Satışı Açıkla," Birgün, July 28, 2016, http:// www.birgun.net/haber-detay/kizilay-meydani-na-dokunma-parsel-parsel-satisi-acikla-121955.html. 
the redefinition of social space per se, and the discursive and building practices of külliyes played an important role in this redefinition. Moreover, similar to the case of toponym changes, an Islamist, populist, and neo-Ottoman emphasis reappeared as a part of this redefinition, as will be discussed in the following section.

\section{The university campus as külliye: A discourse practice moving beyond representation}

The presence of mosques on our university campuses is as important as the presence of faculties. It is not a correct approach to accord one of them importance while neglecting the other.

-Bekir Bozdağ

On January 7, 2015, Turkish president Recep Tayyip Erdoğan made the following statement in his speech at the groundbreaking ceremony for the Esenboğa Campus and the Health Sciences Building of Yildırım Beyazıt University in Ankara:

Regarding the university, the groundbreaking ceremony that we are going to perform today, I had a discussion, or we might call it a consultation, with our Minister of Education over the word "campus." Should it be called a campus? Or should it be called a "neighborhood?" Then I thought about turning back to our history and I said it would be better if we called it a "külliye." It would be the first example in this new era. Thus, instead of being a groundbreaking ceremony for the Esenboğa Campus, the groundbreaking ceremony for the Esenboğa Külliye would be more precise. $^{45}$

Thus, instead of using the word "campus" (kampus) or its Turkish equivalent, yerleşke, to define the space in which a university is located, President Erdoğan deemed the originally Arabic word "külliye" to be "more precise" (daba isabetli), and in so defining this space he created "the first example [of using this word] in this new era." A külliye is "a complex of buildings around a mosque, consisting of a madrasa (Muslim theological school), an imaret (public soup kitchen), a sebil (public water fountain), a library, a hospital, etc., all of which are built together with the mosque." ${ }^{.6}$ In referring to the historical

45 Recep Tayyip Erdoğan, "Yıldııım Beyazıt Üniversitesi'nde Yaptıkları Konuşma," speech, Ankara, January 1, 2015, T.C. Cumhurbaşkanlığı website, https://www.tccb.gov.tr/konusmalar/353/2971/ yildirim-beyazit-universitesinde-yaptiklari-konusma.html.

Güncel Türkçe Sözlük, s.v. "Külliye," http://www.tdk.gov.tr/index.php?option=com_gts\&kelime=Külliye. 
past, Erdoğan alluded to the well-known Islamic külliye complexes of the Ottoman Empire, which were the center of social life, both structurally and institutionally. Külliye spaces were both integral to and organized around a mosque; they represented a complement to a mosque and were managed through a charitable foundation (vakf). In the earlier Ottoman Empire, the concept of a külliye was inherent in the earliest form of a mosque, since one specific building housed the place of prayer, teaching, and hospitality; it was only in later periods that each function was accommodated in its own building located within a larger structure. Though each functional element was structurally separate, together they embodied an architectural and institutional unity ${ }^{47}$ In fact, the word külliye itself is an Ottoman derivation from the Arabic triliteral root kull (ك)), meaning "whole, monolith, totality, or entirety." 48 Thus, in the discursive plane, the külliye is explicitly a representation of space, ${ }^{49}$ specifically a space the center of which is a mosque and around which social life is organized, representing a totality or wholeness with the mosque.

The attempt to define a university campus as a külliye appears as a discursive redefinition of social space according to a specific representation of space, one that pertains to the sociospatial organization proper to the Ottoman period. Furthermore, if one examines other initiatives of the ruling AKP in this context-such as the project of constructing a mosque on every university campus - it appears that this redefinition is not limited to the discursive plane, but also relates to the redefinition of spatial practices. Particularly, in November 2014, the head of the Directorate of Religious Affairs (Diyanet İşleri Başkanliğı), Mehmet Görmez, stated that the construction of mosques for 80 universities throughout the country was underway. Fourteen of these mosques were already open to worship, while 50 mosques were projected to open in 2015. In his statement, Görmez said, "We want mosques to be institutionalized. We do not want mosques to be spaces that are only opened before times of prayer and [then] closed [afterward]. ${ }^{50}$ During the same

47 Godfrey Goodwin, "Külliyye," in The Encyclopedia of Islam, Vol. 5: Khe-Mahi, ed. C.E. Bosworth et al. (Leiden: Brill, 1986), 366.

48 Nişanyan Sözlük: Çağdaş Türkçenin Etimolojisi, s.v. "Külliye," http://nisanyansozluk.com/?k=külliye $\& x=0 \& y=0$.

49 The Lefebvrian notion of the representation of space or conceived space denotes a conceptualized space, such as how scientists, planners, urbanists, social engineers, certain types of artists, etc., conceive, define, and conceptualize space. See Lefebvre, The Production of Space, 38. In this regard, küllye complexes appear as a representation of space in the form of a particular sociospatial organization; namely, the Ottoman sociospatial organization where a mosque at the center of adjacent complementary buildings and structures is conceived of as a unity and totality.

50 "Görmez: 80 Üniversitede Cami Olacak," Hürriyet, November 21, 2014, http://www.hurriyet.com.tr/ gormez-80-universitede-cami-olacak-27615626. 
period, in 2012, then Deputy Prime Minister Bekir Bozdağ's statement, given as an epigraph above, that "the presence of mosques on our university campuses is as important as the presence of faculties" 51 also clearly reveals the representation of space of the Islamist AKP in regard to university campuses. Thus, the initiative to construct a mosque on every campus appears to be the instillation of certain spatial practices that accord with the aforementioned representation of space, and indeed a complete redefinition of social space.

In this redefinition of university campuses as külliye, there is also a third aspect; namely, the representational one. Here, the rejection of both the English loanword "kampus" and its Turkish equivalent, "yerleşke," in favor of appropriating the Arabic "külliye" appears as a representational aspect if one looks at how Islamism in Turkey rejects the concepts, reference points, and values pertaining to modernity, Westernization, and Kemalism. ${ }^{52}$ Külliye - presented by Erdoğan as a "more precise" definition of "campus"is thus revealed as a discursive rejection of a particular word that pertains to the "Western" and the "modern." Hence, the rejection of "campus" proves to be a redefinition of the social space symbolically and mentally, rather than in terms of function and form.

Considering the attempt at the "institutionalization of mosques" in universities as spaces open for both prayer and social activities in tandem with the goal to construct a mosque for every university, it appears that the use of the word "külliye" rather than "kampus" by Erdoğan was not simply a discursive redefinition of space, but also a signifier of an ideology that "only achieves consistency by intervening in social space and in its production, and by thus taking on body therein." ${ }^{53}$ In other words, here the Islamist ideology is attempting to achieve consistency not only through the discursive redefinition of social space, but also through its material transformation, and it also attempts to acquire significance through the everyday use of social space via relevant spatial practices. In this case, this variety of discourse does not simply reference some historical past as an expression of neo-Ottomanism, but, in accordance with Islamist aspirations, it attempts to integrate the mosque with university life and to instil spatial practice according to the aforementioned representation of space. That is to say, it aims to redefine the social space completely.

In January 2016, the secretariat general of the Grand National Assembly of Turkey (Türkiye Büyük Millet Meclisi, TBMM), while preparing documents

51 See "Cami, Fakülte Kadar Önemli!" Cumhuriyet, August 1, 2012, http://www.cumhuriyet.com.tr/haber/ diger/361190/_Cami_fakulte_kadar_onemli_.html.

52 Haldun Gülalp, "Modernization Policies and Islamist Politics in Turkey," in Rethinking Modernity and National Identity in Turkey, ed. Sibel Bozdoğan and Reşat Kasaba (Seattle: University of Washington Press, 1997): 52-63.

53 Lefebvre, The Production of Space, 44. 
for the TBMM's executive board, replaced "the campus of the Grand National Assembly of Turkey" with "the külliye of the Grand National Assembly of Turkey. ${ }^{\prime 54}$ This was another example of instilling the aforementioned representation of space in the discourse, but the essential turning point in this regard was the official redefinition of the Turkish presidential palace as the "Presidential Complex" (Cumburbaşkanliğı Külliyesi). As the following section will show, this new definition of the presidential complex, similar to the case of university campuses, was not simply discursive in nature: it related to the social and material aspects of the social space and bears implications for our understanding of the politics of space and the space of politics, as well as the emergent new sociospatial order in contemporary Turkey.

\section{Discursive, societal, and monumental aspects of the new presidential complex}

When you say Istanbul, seven mosques on seven hills comes to mind; God willing, we are going to make Ankara the same. We are making efforts toward this goal. There is Kocatepe and here is Beştepe.

-Recep Tayyip Erdoğan

The new presidential complex was constructed within the territory of the Atatürk Forest Farm as a service building for the Office of the Prime Minister, utilizing an 18th-century Ottoman-Islamic architectural style. ${ }^{55}$ After the 2014 presidential elections, which represent a turning point in the political history of the Republic of Turkey, it became the residence of President Recep Tayyip Erdoğan. ${ }^{56}$ Erdoğan's relocation to the new site

54 "TBMM 'Külliye' Oldu," Radikal, January 28, 2016, http://www.radikal.com.tr/turkiye/tbmm-kulliyeoldu-1501072/.

55 Ezgi Orhan, "Reflection of Political Restructuring on Urban Symbols: The Case of Presidential Palace in Ankara, Turkey," Journal of Architecture and Urbanism 40, no. 3 (2016), 216.

56 Ibid. As Batuman points out, the new complex serves "not only the representation of the nation as Islamic millet but also the rewriting of the political topology of the capital towards the configuration of the political system centered around a powerful president." Bülent Batuman, New Islamist Architecture and Urbanism: Negotiating Nation and Islam through Built Environment in Turkey (Routledge, 2017), 154. For more details about the planning and legal issues involved in the construction of the Presidential Complex on the territory of the Atatürk Forest Farm, see Deniz Kimyon and Gencay Serter, "Atatürk Orman Çiftliği'nin ve Ankara'nın Değişimi Dönüşümü," Planlama 25, no. 1 (2015): 44-63. For a detailed analysis of the architectural style and symbolic aspects of the complex, see Orhan, "Reflection of Political Restructuring"; Batuman, New Islamist Architecture. Batuman's book is the most complete recent account of not only the architectural and symbolic aspects of the new presidential palace and complex, but also presents a detailed overview of Islamist architecture in Turkey in recent years. 
not only after the elections, ${ }^{57}$ but also after accepting congratulations in the complex on the occasion of Republic Day on October 29, 2014, served as a symbolization of this turning point, especially as this same day marked the starting date of the official use of this palace ${ }^{58}$ Çankaya Palace, the former presidential residence, had been chosen as a residence by Mustafa Kemal in the 1920s. Although Çankaya Palace underwent numerous transformations, it had always held a central place, at least in the representational space of Ankara. Indeed, Çankaya Palace has been always identified with the secular Republic of Turkey and its foundational principles. After the 1950s, the mausoleum of Mustafa Kemal Atatürk, Anttkabir, began to rise in the urban space of Ankara. This mausoleum, along with Çankaya Palace, further contributed to the secular republican identity of Ankara. After the 1980s, however, this identity started to erode with the appearance of Kocatepe Mosque in a central district of Ankara. ${ }^{59}$ In this respect, the 2014 completion of the new presidential complex in Beştepe, which became the residence of the first elected president of the republic, was a major turning point in the gradual transformation of the urban skyline and image of Ankara ${ }^{60}$ Moreover, the president's acceptance of congratulations on the occasion of Republic Day in 2014 in the new palace not only clearly showed the change in the urban skyline of Ankara, but also symbolically reflected the change in Ankara's long-established representational space.

The new presidential complex redefined the urban skyline and symbolized the new turn in the republic's political history, not only via its "18th-century

57 President Erdoğan relocated from the Foreign Affairs Residence Building, located in the Çankaya district of Ankara, to the State Guesthouse of the Presidential Palace on December 7, 2015. "Cumhurbaşkanı Erdoğan, Beştepe'deki Devlet Konukevi'ne taşındı," Hürriyet, December 19, 2015, http://www.hurriyet.com.tr/cumhurbaskani-erdogan-bestepedeki-devlet-konukevine-tasindi40029315.

58 "29 Ekim Resepsiyonu İptal," Hürriyet, October 29, 2014, http://www.hurriyet.com.tr/29-ekimresepsiyonu-iptal-27477903.

59 For detailed accounts of these transformations, see Michael E. Meeker, "Once There Was, Once There Wasn't: National Monuments and Interpersonal Exchange," in Rethinking Modernity and National Identity in Turkey, ed. Sibel Bozdoğan and Reşat Kasaba (Seattle: University of Washington Press, 1997): 157-191; Çınar, "The Imagined Community"; Sargın, "Displaced Memories."

60 Later, on July 3, 2015, while speaking at the opening ceremony of the Beştepe National Mosque within the territory of the Presidential Palace, Erdoğan stated as follows: "When you say İstanbul, seven mosques on seven hills comes to mind; God willing, we are going to make Ankara the same. We are making efforts toward this goal. There is Kocatepe and here is Beştepe." "Erdoğan, Beştepe Millet Camii Açılışında Konuştu," Hürriyet, July 3, 2015, http://www.hurriyet.com.tr/erdogan-bestepemillet-camii-acilisinda-konustu-29450429. This statement clearly shows the kind of representation of space and city that the ruling AKP envisions regarding the capital Ankara; indeed, it emphasizes the recent deliberate and conscious attempts by the AKP to transform Ankara according to its own systems of representation. 
Ottoman-Islamic" or "Ottoman-Seljuk" architecture, ${ }^{61}$ but also with the official identification of the complex as a külliye in 2015, a redesignation that bears certain other interesting implications in terms of both discourse and practice.

Just after the opening of the Beştepe National Mosque (Beştepe Millet Camii) - located on the grounds of the presidential palace-for prayers on July 3, 2015, the site was officially renamed the Presidential Complex (Cumburbaşkanliğı Külliyesi). ${ }^{62}$ As noted above, a külliye is a complex of buildings around a mosque, in which the mosque serves as the focal point. As a result, two ironic points arise in connection with the Presidential Complex: first, the complex as a whole had been conceived earlier, with the mosque only being added to it later; second, with the redesignation, the presidential residence of a secular republic was identified as a külliye, a term with clear Islamic connotations. Nevertheless, these ironies indirectly reflect certain important features of the complex. For one, the mosque is not the center of this space, lacking the centrality and definitive function for the space, because the space's essential center is the presidential palace, the locus of political power. In this regard, this constellation of the mosque and the presidential palace, together defined as the Presidential Complex (külliye), represents a transformation and reflects the current status of political Islam in Turkey. The center of the Presidential Complex is not actually the mosque, but the residence or locus of power, while the mosque fulfills only a representative function. In other words, the Presidential Complex effectively symbolizes the rise of political Islam over the course of the post- 1980 period: its rise to and subsequent solidification of power, as well as its exclusive use of the religious domain as representation, while all that matters revolves at the nearby presidential palace. Thus, the Presidential Complex, although termed a külliye, in fact emerges as the representational space specifically of political Islam in contemporary Turkey.

The other aspect worth elaborating upon is the fact that, even though the complex is identified as a külliye, its külliye aspect also reflects other important realities. As noted above, the word külliye came into Turkish from Arabic,

61 While Orhan considers the architecture of the new presidential palace to be $18^{\text {th }}$-century Ottoman Islamic architecture, according to Batuman it is a synthesis in the Seljuk-Ottoman style. According to Batuman, with its unmistakable references to the Second National Architectural Style and the "Turkish House" type and its not-so-subtle references to the Western classical architectural tradition, the new palace appears as a "hybridization of Western classicism with the nationalist architectures of the twentieth century," and thus proves to be a kind of "new synthesis merging Turkish Islam with Western classicism." Orhan, "Reflection of Political Restructuring," 216; Batuman, New Islamist Architecture, 154-201. Also see Ali Uzay Peker, "AKP Döneminde Rövanşist Mimari," Mimarlık 386 (2015): 4-19.

62 "Erdoğan, Beştepe Millet Camii Açılışında Konuştu," Hürriyet, July 3, 2015, http://www.hurriyet.com.tr/ erdogan-bestepe-millet-camii-acilisinda-konustu-29450429; "Saray Artık Resmen 'Külliye' Oldu," T24, July 7, 2015, http://t24.com.tr/haber/adi-resmen-cumhurbaskanligi-kulliyesi-oldu,302106. 
with its root meaning "whole, monolith, totality, or entirety." In this regard, the Presidential Complex not only dominates the skyline of Ankara as a monumental structure, but also dominates the entire national space, as it reportedly contains a control center possessing the following abilities: 1) the ability to monitor all closed-circuit television systems in Turkey's 81 provinces through the MOBESE (Mobile Electronic System Integration) system; 2) the ability to record the transmissions of this system on three massive servers; and 3) the ability to access and monitor transmissions from drones, television stations, and $3 \mathrm{G}$ networks. Furthermore, also linked to the center are the Gendarmerie; the Directorate of Disaster and Emergency Management (Afet ve Acil Durum Yönetimi Başkanliğı, AFAD); the Information and Communication Technologies Authority (Bilgi Teknolojileri ve İletişim Kurumlari); and the National Intelligence Service (Millî İstibbarat Teşkilatı, MİT). ${ }^{63}$ All of these features, while highlighting the Presidential Complex's function as a kind of panopticon monitoring, policing, and dominating the entire national space, also show that the specific designation of the complex as a külliye is not entirely ironic and contradictory: after all, on the discursive plane, külliye means "totality" and "entirety." Hence, the Presidential Complex acting as a center of control, surveillance, and domination with these characteristics appears as a conceived space. ${ }^{64}$

In early 2015, when the Presidential Complex was not yet officially identified as a külliye, President Erdoğan discussed the possible nomination of the complex as a kulliye:

This Presidential Palace is for now a palace, but shortly it will become the Presidential Complex (Cumburbaşkanliğı Külliyesi). Why a külliye? Because right next door, the construction of a convention center is underway. There is no large mosque for Friday prayers in this district; and so, just behind the convention center, we are building such a mosque. In the same way, on the right side of the convention center there will be a multi-purpose hall that would allow a

63 Fehim Taştekin, "Big Brother' to Move into Erdogan's Palace," Al-Monitor, March 13, 2015, http://www. al-monitor.com/pulse/originals/2015/03/turkey-big-brother-erdogan-palace.html. On August 28, 2017, on the occasion of third year of assuming the presidency, Erdoğan noted the following: "We didn't have an operational center in Çankaya Palace, but in Beştepe we have one. In this center, we have the representatives not only of our ministers, but also of our other important establishments as well, and the center works round the clock. We keep an eye on the entire country from this center. Moreover, in the center we have an opportunity to contact the governors of the 81 provinces as well." See "Erdoğan: İstihbaratın Başı Devletin Başına Bağlı Olmalı," Birgün, August 28, 2017, https://www. birgun.net/haber-detay/erdogan-istihbaratin-basi-devletin-basina-bagli-olmali-176920.html.

64 Conceived of and designed as a center of surveillance, control, and domination over the entire national space, the Presidential Complex pertains to the Lefebvrian notion of the representation of space (conceived space) because it appears as the center of a conceived national space where the entire national space is controlled, policed, and dominated from one place; namely, the Presidential Complex. See Lefebvre, The Production of Space, 38. 
meeting of two thousand people at the same time. I mean meetings with meals, and our purpose is to organize some large meetings like this there. We want to make this a place where our neighborhood representatives (mubtar) can easily come and go. ${ }^{65}$

As is clear from the above statement, the Presidential Complex was designed as a full-service space with various spatial arrangements meant to cater to the needs of visiting neighborhood representatives. In the hierarchy of governance, neighborhood representatives (mubtar) represent the state's closest connection to ordinary people at the village and neighborhood levels. Thus, typical meetings between President Erdoğan and neighborhood representatives seek to exhibit the Presidential Complex as a locus of national space that accommodates the encounter between common people and the presidential authority. This spatial practice fits in perfectly with the populist rhetoric of the AKP, in which the AKP and its leader Erdoğan are directly presented as representatives of the common people. As such, the Presidential Complex, as a center accommodating the meeting of governor and governed, emerges as a representational space of populist rhetoric and practice. Furthermore, in this manner, the AKP is also trying to counter the early period of the Republic of Turkey, when, during the one-party rule of the Kemalist era, ordinary people were excluded from political life-a fact that the AKP has consistently used as a way of building its populist rhetoric. Thus, the Presidential Complex has also become a relevant case for the spatialization of the AKP's populist rhetoric, one which pertains to the representational aspect of this space. On October 28, 2015, during the reception organized in the Presidential Complex on the occasion of Republic Day, President Erdoğan referred to the early periods of the republic as follows:

On the one hand, there were Republic Day celebrations with full dress suits, waltzes, and champagne, while just outside the door a people/nation (millet) without shoes on their feet or a jacket on their shoulders, [a people] half-hungry and trying to stay alive, were watching this scene with astonishment [...] The public - that is, the will of the people-was attacked under the name of the republic. The word "republic" was always used as a cover for onslaughts against democracy, freedoms, law - in short, all the achievements of the people/nation (millet) - in order that [their] guardianship (vesayet) could be protected. Those who did not have the least connection with the essence of the republic exploited the notion [of the republic] in order to maintain their ideology and the hidden power of their

65 "Cumhurbaşkanlığı Sarayı Külliye Oluyor," Milliyet, January 16, 2015, http://www.milliyet.com.tr/ cumhurbaskanligi-saray-kulliye/siyaset/detay/1999587/default.htm. 
own interests [...] And the Presidential Complex in which we currently stand symbolizes the reunion of the ordinary people with the state, and it symbolizes the fact that the owner of the republic is not this or that establishment or faction, but the public itself [...] From now on, the owner of the republic is our people/nation (millet) and the Presidential Complex is its symbol [...] In the past, the presidential office was a place where only one identity, only one way of thought, only one lifestyle was dominant, and only those possessing these qualities could enter through its doors. Today, now, the presidential office is a place that hosts and cherishes citizens of every region and every part of the nation. ${ }^{66}$

This statement clearly reinforces the populist rhetoric of the AKP as supposed representatives of the common people, who are "the real owners of the nation" in opposition to the "guardians, who do not want their development." At the same time, the AKP is also presented as representative of the nation and the only force that can stand against the "guardians." In this narrative, the Presidential Complex is highlighted as a product of the struggle against guardianship foci and thus appears as the representational space of "the people as the real owners of the republic."

According to Lefebvre, "monumental space offer[s] each member of a society an image of that membership, an image of his or her social visage. It thus constitute[s] a collective mirror more faithful than any personal one"; and through this collective mirror, "the monument thus effect[s] a 'consensus,' and this in the strongest sense of the term, rendering it practical and concrete." 67 In this regard, Erdoğan's statement that "from now on, the owner of the republic is our people/ nation and the Presidential Complex is its symbol," and that the Presidential Complex "symbolizes the reunion of the ordinary people with the state, and [...] the fact that the owner of the republic is not this or that establishment or faction, but the public itself' could be considered an attempt to present a collective mirror for society. In his speech, Erdoğan also attempts to define this space as, in Lefebvre's words, "a collective mirror more faithful than any personal one," and as a monumental space that effects a societal "consensus" for a part of society and renders that consensus "practical and concrete": "This [complex] is not my personal home but the home of the people/nation (millet). With this work, a different image is presented to the world. This work shows the greatness of this nation (millet)." 68

66 Recep Tayyip Erdoğan, "Cumhuriyetin Sahibi Milletimizin Kendisidir, Sembolü de Cumhurbaşkanlığı Külliyesidir," speech, Ankara, October 28, 2015, T.C. Cumhurbaşkanlığı website, http://www.tccb.gov. tr/haberler/410/35788/cumhuriyetin-sahibi-milletimizin-kendisidir-sembolu-de-cumhurbaskanligikulliyesidir.html.

67 Lefebvre, The Production of Space, 220.

68 "Erdoğan: Bu Girişimdekilere Ben 'Mankurt' Diyorum," Radikal, October 19, 2015, http://www.radikal. com.tr/turkiye/erdogan-bu-girisimdekilere-ben-mankurt-diyorum-1454938. 
In discussing the populist rhetoric of the AKP, which has been working to present the Presidential Complex as a meeting place between ordinary people and the ruling power, it is worth briefly noting some of the features of the former presidential palace, Çankaya Palace, during the period of Kemalist rule. This will be an aid in understanding the politics of space of the populist AKP as compared to earlier periods of the republic, while also helping to provide some historical context for the AKP's populist rhetoric.

As mentioned above, the former presidential palace was chosen by Mustafa Kemal as a residence in the 1920s, and subsequently it has always been identified with the secular republic and its foundational principles, an identification that applied to all the conceived, perceived, and lived aspects of the palace. The Kemalist elite, and particularly Mustafa Kemal Atatürk, considered themselves and their own lifestyles as exemplary of their mission to modernize and Westernize Turkish society. ${ }^{69}$ Thus, as Akcan notes, their houses were designed in such a way as to show the people how modern dwellings and modern lifestyles should be. Moreover, their houses were designed as emblems of Westernization and modernization, and as proof to the world outside that Turkish bureaucrats had freed themselves from "Oriental" habits. In other words, along with their functions as dwellings, the houses were also a propaganda tool for the state and a stage for a nationalist showcase. Çankaya Palace, through both its location in the city and its frequent coverage in the media, clearly evidences these functions of the palace. ${ }^{70}$ Thus, in this regard, the palace was a representation of the space of the Kemalist elite's attempts at modernization and Westernization. ${ }^{71}$

The representational aspects of the palace, however, went far beyond its architectural style and location. As Cantek notes, during the lifetime of Atatürk, the palace operated as a unique stage for frequent activities (i.e., spatial practices) such as evening parties, and it was a frequent focus for the media of the time as well. Through such activities, Atatürk and the Kemalist elite sought to popularize the modern and Western urban lifestyle among the ordinary population. ${ }^{72}$ These spatial practices were closely related to the

69 In this regard, the following words of Mustafa Kemal Atatürk may prove instructive: "I don't get married just to get married. In order to create a new family life for our nation, I have to first be exemplary myself." Cited in Esra Akcan, Çeviride Modern Olan: Şehir ve Konutta Türk-Alman Illişkileri (İstanbul: YKY, 2009), 88.

70 See Akcan, Çeviride Modern Olan, 86-87.

71 As Lefebvre notes, "representations of space have a practical impact, they intervene in and modify spatial textures which are informed by effective knowledge and ideology"; Lefebvre, The Production of Space, 42. Thus, Çankaya Palace was an intervention by the ideologically motivated modernist and pro-Western rhetoric of the Kemalists into the spatial texture, and could therefore be conceptualized as the conceived space of the modernization attempts of Kemalism.

72 For a detailed account, see Cantek, "Yaban"lar ve Yerliler. 
representation-of-space aspect of the palace, which, as Akcan points out, was "not a private space, but a space blurring the definition of private and public," since it served as a stage for both official and unofficial meetings. ${ }^{73}$ Even so, the palace with its "openness," and alongside the public spaces of the city generally, which were the center of "Western" and "modern" spatial practices, were, as Nalbantoğlu notes, a factor in significant tensions resulting from encounters between old (i.e., traditional, rural) and new (i.e., modern, urban) ${ }^{74}$ The monumental architecture and urban spaces of the city of Ankara appeared as "sanitized" spaces aimed at guarding the "modern" image of the city, and there were cultural and spatial boundaries in the capital that were delineated with the utmost care in order to protect the "modernist" grand narrative of the time from "non-Western" and "non-modern" meanings and values. ${ }^{75}$ It is in this context that the aforementioned policing and dress-code enforcement practices seen during the time of Nevzat Tandoğan complete the grand picture. It is exactly this aspect of early republican Ankara and the attempts of the Kemalist elite to create a "modern" urban experience that created tensions between old and new, between the elites (with their modern lifestyles) and the common people (with their traditional way of life and exclusion from the public space). It is against this background that President Erdoğanreferring to celebrations where participants wore full dress suits, danced waltzes, and drank champagne while poorly clothed ordinary people looked on in astonishment from outside-worked to present the Presidential Complex as a place that "hosts and cherishes citizens of every region and every part of the nation." Based on this background narrative, Erdoğan positioned his power as the representative of the ordinary people, and this narrative is precisely the reason that the Presidential Complex emerges as a representational space that reflects the spatialization of populist discourse in the Turkish capital. However, it remains to be explored whether and how the Presidential Complex has contributed to spatial and cultural tensions in the capital and the nation, a topic that goes beyond the limits of this paper.

\section{Conclusion}

This article has analyzed the politics of space and the space of politics in post2000 Turkey through a focus on the spatial politics of the AKP and an

73 Akcan, Çeviride Modern Olan, 89-102.

74 Gülsüm Baydar Nalbantoğlu, "Silent Interruptions: Urban Encounters with Rural Turkey," in Rethinking Modernity and National Identity in Turkey, ed. Sibel Bozdoğan and Reşat Kasaba (Seattle: University of Washington Press, 1997), 194.

For a detailed account of the issue, see Nalbantoğlu, "Silent Interruptions," 199. 
examination of several cases in the capital, Ankara. In evaluating the politics of space, and particularly the changing discourse over the space in question, the article focused specifically on recent toponym changes in the Turkish capital, on discussions centering on the redenomination of university campuses as külliye, and on the development of the new Turkish Presidential Complex (Cumburbaşkanliğı Külliyesi). As a result of analysis of these cases, it appears that in all of them, three particular factors unique to the AKP have dominated the politics of space in the Turkish capital-namely, Islamism, neoOttomanism, and populism - and in the cases examined, one can speak of the spatialization of Islamist, neo-Ottoman, and populist discourses in the Turkish capital under AKP rule. In particular, the analysis shows that, over the last decade, the AKP — as an Islamist political party in power and as a political party that makes frequent reference to the Ottoman past-has engaged in a significant effort to redefine the representational spaces of the Turkish capital according to its own Islamist and pro-Ottoman vision. For instance, approximately 23 percent of the new toponyms in the capital variously refer to Seljuk/Ottoman historiography (the main historiographical reference point for the AKP) or to Islam. Moreover, in the case of toponym changes, one can see a spatialization of the AKP's populist rhetoric, with the case of Tandoğan Square being a clear example. Additionally, the spatialization of Islamist, neo-Ottoman, and populist discourses has been the constitutive part of the recent discourse revolving around university campuses, and especially the new presidential complex. The most significant aspect of the recent discourse centered on the word and concept of külliye, however, is the attempt by an Islamist power to define not only the representational aspects of space (i.e., those aspects that pertain to the mental sphere), but also its practical aspects. As shown in the case of university campuses, the redefinition of campuses as külliye goes beyond a simple redefinition in representational and mental terms, with the attempt of the Islamist AKP to institutionalize mosques and make them an integral part of university campuses indicating how the külliye discourse goes well beyond the representational realm to actually impact the practical realm. Thus, the case of the külliye discourse can be read as an attempt by the ruling power to redefine social space through both discursive and building practices and arrangements that seek not only to redefine the representational aspects of a given social space, but also to transform the everyday use and experience of that social space. As such, the recent külliye discourse and building practices relate to the redefinition both of the representational aspects of space and of spatial practices taking place in the Turkish capital.

As the final object of analysis, particular attention was paid to Turkey's new presidential palace complex, which provides important insights into the 
emerging new sociospatial order in Turkey and can be considered a kind of summary of the recent contradictory and at times ironic transformation of Turkish society. Focusing on the representational aspects of the Presidential Complex, the article concluded that, although the official name of the complex of the secular Republic of Turkey ironically bears clear Islamic connotations via its employment of the word külliye, this denomination actually does reflect the nature of this complex as a dominating, controlling center for the entire national space of Turkey, features that are quite pertinent to the complex's identification as a külliye in the discursive plane. The paper also concluded that there are some especially interesting details on the discursive plane regarding how this complex is presented and described. In particular, along with the ruling AKP's Islamic features, another important characteristic of the party has been its populist rhetoric, and in this regard the Presidential Complex is a space whose characteristic feature is not a dominant central mosque-as in any traditional külliye complex-but instead the locus of political power. Thus, the Presidential Complex serves as a representational space of both political Islam and the populist politics of Turkey. Being described as a symbol of the new order of Turkey that instantiates concepts of the reunion of the people and the state and of the people as the republic's true

owners, the Presidential Complex functions as a representational space of populist politics and discourse even as it functions as a representational space for the AKP as supposed representatives of ordinary people. Moreover, as a highly monumental space, the complex is presented by the AKP as a Lefebvrian collective mirror for, at least, that part of society that now underpins Turkey's new social and spatial order under the rule of Recep Tayyip Erdoğan and the AKP. This article has not investigated whether or not presidential complexes in general reflect the dominant sociospatial order of different nations either on a discursive plane or in the built environment, but from the analysis presented here, one point is clear: the new presidential palace complex of the Republic of Turkey, the Presidential Complex or Külliye, is a clear reflection of the emerging sociospatial order in Turkey.

\section{Acknowledgements}

This paper is based on the author's doctoral dissertation completed under the supervision of Prof. Tayfun Cinar in 2017 at the Graduate School of Social Sciences of Ankara University. However, substantial revisions were made, and additional comments added to support the main arguments. 
The author would like to express his appreciation to Michelle Yeoman, Amber Murrey, Biray Kolluoğlu and three anonymous reviewers for their valuable comments, criticism, and support.

\section{Funding statement or Declaration of conflicting interests}

This research did not receive any specific grant from funding agencies in the public, commercial, or not-for-profit sectors.

\section{References}

“\% 65’in Yüzbinleri.” Hürriyet. April 15, 2007. http://www.hurriyet.com.tr/gundem/65-in-yuzbinleri6335051.

“29 Ekim Resepsiyonu İptal." Hürriyet. October 29, 2014. http://www.hurriyet.com.tr/29-ekim-resepsiyonuiptal-27477903.

Akcan, Esra. Çeviride Modern Olan: Şehir ve Konutta Türk-Alman Iliş̧kileri. İstanbul: YKY, 2009.

“AKP’ye ‘Barış' Fazla Geldi: Gar Meydanı'nın Adı ‘Demokrasi Meydanı' Olarak Değiştirildi.” Diken. October 15, 2015. http://www.diken.com.tr/akpye-baris-fazla-geldi-gar-meydaninin-adi-demokrasi-meydaniolarak-degistirildi/.

Ankara Büyükşehir Belediyesi. "1071 Malazgirt Bulvarı'na Muhteşem Açılış.” Büyükşehir Ankara 10, no. 470 (2014).

. "Değişen Cadde ve Sokak İsimleri." https://www.ankara.bel.tr/genel-sekreter-yardimcisi-vedatucpinar/fen-isleri-dairesi-baskanligi/numarataj-sube-mudurlugu/degisen-cadde-ve-sokak-simleri.

“Ankara Explosions Leave Almost 100 Dead." BBC News. October 10, 2015. http://www.bbc.com/news/ world-europe-34495161.

“Ankara'da Laiklik Yanlısı Gösteri.” BBC Turkish. April 14, 2007. http://www.bbc.co.uk/turkish/news/story/ 2007/04/070414_turkey_rally_update.shtml.

“Ankara'daki Barış Mitingini Kim Düzenledi ve Kimler Katıldı?” Sözcü. October 10, 2015. http://www.sozcu. com.tr/2015/gunun-icinden/ankaradaki-baris-mitingini-kim-duzenledi-ve-kimler-katildi-956109/.

Batuman, Bülent. "Mekân, Kimlik ve Sosyal Çatışma: Cumhuriyet'in Kamusal Mekânı Olarak Kızılay Meydanı.” In Ankara'nın Kamusal Yüzleri: Başkent Üzerine Mekân-Politik Tezler. Edited by Güven Sargın. İstanbul: İletişim, 2002. 41-76.

—. New Islamist Architecture and Urbanism: Negotiating Nation and Islam through Built Environment in Turkey. Routledge, 2017.

Bayhan, Bahar. "Kızılay Meydanı'nın Adının Değiştirilmesiyle İlgili Mimarlar Odası'ndan Açıklama.” Arkitera. July 27, 2016. http://www.arkitera.com/haber/27289/kizilay-meydaninin-adinin-degistirilmesi-karariyle-ilg

Bozdoğan, Sibel and Esra Akcan. Turkey: Modern Architectures in History. London: Reaktion Books, 2013.

"Cami, Fakülte Kadar Önemli!" Cumhuriyet. August 1, 2012. http://www.cumhuriyet.com.tr/haber/diger/ 361190/_Cami_fakulte_kadar_onemli_.html.

Cantek, Funda Şenol. "Yaban"lar ve Yerliler: Başkent Olma Sürecinde Ankara. İstanbul: İletişim, 2003.

“Cumhurbaşkanı Erdoğan, Beştepe'deki Devlet Konukevi'ne Taşındı.” Hürriyet. December 19, 2015. http:// www.hurriyet.com.tr/cumhurbaskani-erdogan-bestepedeki-devlet-konukevine-tasindi-40029315.

"Cumhurbaşkanlığı Sarayı Külliye Oluyor." Milliyet. January 16, 2015. http://www.milliyet.com.tr/ cumhurbaskanligi-saray-kulliye/siyaset/detay/1999587/default.htm.

Çınar, Alev. Modernity, Islam, and Secularism in Turkey: Bodies, Places, and Time. Minneapolis: University of Minnesota Press, 2005.

. "The Imagined Community as Urban Reality: The Making of Ankara." In Urban Imaginaries Locating the Modern City. Edited by Alev Çınar and Thomas Bender. Minneapolis: University of Minnesota Press, 2007. 151-181. 
Dikeç, Mustafa. "Space as a Mode of Political Thinking." Geoforum 43, no. 4 (2012): 669-676.

Doğan, Ali Ekber. “Gökçek’in Ankara'yı Neo-Liberal Rövanşçılıkla Yeniden Kuruşu.” Planlama 2005/4 (2005): 130-138.

—. Eğreti Kamusallık: Kayseri Örneğinde İslamcı Belediyecilik. İstanbul: İletişim, 2007.

Doğanay, Ülkü. "Türkiye'de Siyasal İslam ve Kentsel Mekânlar: Fazilet (Refah) Partili Büyükşsehir Belediyesi'nin Ankara'daki Uygulamaları.” Çağdaş Yerel Yönetimler Dergisi 9, no. 1 (1999): 3-19.

Durgun, Sezgi. Memalik-i Şahane'den Vatan'a. İstanbul: İletişim, 2011.

Dündar, Can. Twitter post. February 15, 2014. https://twitter.com/candundaradasi/status/4347853084 00291840.

Elden, Stuart. "There Is a Politics of Space Because Space Is Political: Henri Lefebvre and the Production of Space." Radical Philosophy Review 10, no. 2 (2007): 106-107.

"Erdoğan, Beştepe Millet Camii Açılışında Konuştu." Hürriyet. July 3, 2015. http://www.hurriyet.com.tr/ erdogan-bestepe-millet-camii-acilisinda-konustu-29450429

“Erdoğan: Bu Girişimdekilere Ben 'Mankurt' Diyorum.” Radikal. October 19, 2015. http://www.radikal.com. tr/turkiye/erdogan-bu-girisimdekilere-ben-mankurt-diyorum-1454938.

“Erdoğan: İstihbaratın Başı Devletin Başına Bağlı Olmalı." Birgün. August 28, 2017. https://www.birgun.net/ haber-detay/erdogan-istihbaratin-basi-devletin-basina-bagli-olmali-176920.html.

Erdoğan, Recep Tayyip. "Cumhuriyetin Sahibi Milletimizin Kendisidir, Sembolü de Cumhurbaşkanlığı Külliyesidir.” Speech, Ankara, October 28, 2015. T.C. Cumhurbaşkanlığı website. http://www.tccb. gov.tr/haberler/410/35788/cumhuriyetin-sahibi-milletimizin-kendisidir-sembolu-de-cumhurbaskanligikulliyesidir.html.

—. "Yıldıım Beyazıt Üniversitesi'nde Yaptıkları Konuşma." Speech, Ankara, January 1, 2015. T.C. Cumhurbaşkanlığı website. https://www.tccb.gov.tr/konusmalar/353/2971/yildirim-beyazituniversitesinde-yaptiklari-konusma.html.

Foucault, Michel. Security, Territory, Population: Lectures at the College de France 1977-1978. Edited by Michel Senellart. Translated by Graham Burchell. New York: Picador, 2007.

Goodwin, Godfrey. "Külliyye. "In The Encyclopedia of Islam, Vol. 5, Khe-Mahi. Edited by Clifford Edmund Bosworth, Emeri van Donzel, Bernard Lewis, and Charles Pellat. Leiden: Brill, 1986.

Göle, Nilüfer. "Secularism and Islamism in Turkey : The Making of Elites and Counter-Elites." Middle East Journal 51, no. 1 (1997): 46-58.

"Görmez: 80 Üniversitede Cami Olacak." Hürriyet. November 21, 2014. http://www.hurriyet.com.tr/ gormez-80-universitede-cami-olacak-27615626.

Gregory, Derek and John Urry, eds. Social Relations and Spatial Structures. London: Macmillan, 1985.

Gülalp, Haldun. "Modernization Policies and Islamist Politics in Turkey." In Rethinking Modernity and National Identity in Turkey. Edited by Sibel Bozdoğan and Reşat Kasaba. Seattle: University of Washington Press, 1997. 52-63.

“Kızılay Meydanı'na Dokunma, Parsel Parsel Satışı Açıkla.” Birgün. July 28, 2016. http://www.birgun.net/ haber-detay/kizilay-meydani-na-dokunma-parsel-parsel-satisi-acikla-121955.html.

Kimyon, Deniz and Gencay Serter. "Atatürk Orman Çiftliği'nin ve Ankara'nın Değişimi Dönüşümü." Planlama 25, no. 1 (2015): 44-63.

Koç, Mert Gökhan. "Gar Meydanı Demokrasi Meydanı Oldu." Hürriyet. October 15, 2015. http://www. hurriyet.com.tr/gar-meydani-demokrasi-meydani-oldu-30323097.

Koyuncu, Büke. "Benim Milletim ... .": AK Parti İktidarı, Din ve Ulusal Kimlik. İstanbul: İletişim, 2014.

Köprülü, Ahmet. “ODTÜ Yolu'na, '1071 Malazgirt Bulvarı' Adı Verildi.” Büyükşehir Ankara 10, no. 469 (2014): 16-17.

“Külliye.” Güncel Türkçe Sözlük. http://www.tdk.gov.tr/index.php?option=com_gts\&kelime=Külliye.

"Külliye." Nişanyan Sözlük: Çağdaş Türkçenin Etimolojisi. http://nisanyansozluk.com/?k=külliye\&x=0\&y=0.

Lefebvre, Henri. Survival of Capitalism: Reproduction of the Relations of Production. Translated by Bryant Frank. New York: St. Martin's Press, 1976.

—. The Production of Space. Translated by Donald Nicholson-Smith. Cambridge, MS: Blackwell, 1991.

Massey, Doreen. "Politics and Space/Time." New Left Review 196 (1992): 65-84.

—. Spatial Divisions of Labour: Social Structures and the Geography of Production. London: Macmillan, 1995. 
Meeker, Michael E. "Once There Was, Once There Wasn't: National Monuments and Interpersonal Exchange." In Rethinking Modernity and National Identity in Turkey. Edited by Sibel Bozdoğan and Reşat Kasaba. Seattle: University of Washington Press, 1997. 157-191.

Morris, Chris. "Despatches." BBC News. January 16, 1998. http://news.bbc.co.uk/2/hi/middle_east/48001.stm. Nalbantoğlu, Gülsüm Baydar. "Silent Interruptions: Urban Encounters with Rural Turkey." In Rethinking Modernity and National Identity in Turkey. Edited by Sibel Bozdoğan and Reşat Kasaba. Seattle: University of Washington Press, 1997. 192-210.

Orhan, Ezgi. "Reflection of Political Restructuring on Urban Symbols: The Case of Presidential Palace in Ankara, Turkey." Journal of Architecture and Urbanism 40, no. 3 (2016): 206-219.

Özkan, Miray and Ali Cenap Yoloğlu. "Bir Bellek Projesi Olarak Sokak İsimlendirmesi: Ankara Örneği." Planlama 2005/4 (2005): 54-60.

Peker, Ali Uzay. “AKP Döneminde Rövanşist Mimari,” Mimarlık 386 (2015): 4-19.

Saraçoğlu, Cenk and Melih Yeşilbağ. “AKP Döneminde Türkiye: Minare Ile İnşaat Gölgesinde.” In Osmanlidan Günümüze Türkiye'de Siyasal Hayat. Edited by Gökhan Atılgan, Cenk Saraçoğlu, and Ateş Uslu. İstanbul: Yordam Kitap, 2015. 871-957.

“Saray Artık Resmen ‘Külliye’ Oldu.” T24. July 7, 2015. http://t24.com.tr/haber/adi-resmen-cumhurbaskanligikulliyesi-oldu,302106.

Sargın, Güven Arif. "Displaced Memories, or the Architecture of Forgetting and Remembrance." Environment and Planning D: Society and Space 22, no. 5 (2004): 659-680.

- "Sincan, a Town on the Verge of Civic Breakdown: The Spatialization of Identity Politics and Resistance." In Visualizing Secularism and Religion: Egypt, Lebanon, Turkey, India. Edited by Alev Çınar, Srirupa Roy, and Maha Yahya. Ann Arbor: The University of Michigan Press, 2012. 258-280.

Semerci, Tansel. "Tandoğan Meydanı, 'Anadolu Meydanı' Oldu.” Büyükşehir Ankara 11, no. 528 (2015): 28-29.

Soja, Edward. "The Socio-Spatial Dialectic." Annals of the Association of American Geographers 70, no 2 (1980): 207-225.

- Postmodern Geographies: The Reassertion of Space in Critical Social Theory. London: Verso, 1989.

“Tandoğan Meydanı'nın İsmi ‘Anadolu Meydanı' Olarak Değiştirildi.” CNN Türk. April 13, 2015. http://www. cnnturk.com/haber/turkiye/tandogan-meydani-nin-ismi-anadolu-meydani-olarak-degistirildi.

“Tandoğan Meydanı'nın İsmi Değişti." Radikal. May 14, 2012. http://www.radikal.com.tr/turkiye/tandoganmeydaninin-ismi-degisti-1088027/.

“Tandoğan Meydanı'nın İsminin Değişmesi İçin Teklif.” Hürriyet. April 18, 2012. http://www.hurriyet.com. tr/tandogan-meydaninin-isminin-degismesi-icin-teklif-20369695.

Taştekin, Fehim. "'Big Brother' to Move into Erdogan's Palace." Al-Monitor. March 13, 2015. http://www.almonitor.com/pulse/originals/2015/03/turkey-big-brother-erdogan-palace.html.

“TBMM 'Külliye' Oldu.” Radikal. January 28, 2016. http://www.radikal.com.tr/turkiye/tbmm-kulliye-oldu$1501072 /$.

“Turkey Bans Islamic Party." BBC News. June 22, 2001. http://news.bbc.co.uk/2/hi/europe/1402927.stm.

West-Pavlov, Russell. Space in Theory: Kristeva, Foucault, Deleuze. New York: Rodopi, 2009.

Yaşlı, Fatih. AKP, Cemaat, Sünni-Ulus: Yeni Türkiye Üzerine Tezler. İstanbul: Yordam Kitap, 2015.

Yıldırım, Uğur. "Malazgirt Atışması." Sabah. February 19, 2014. http://www.sabah.com.tr/ankara-baskent/ 2014/02/19/malazgirt-atismasi.

Zencirci, Gizem. "Secularism, Islam, and the National Public Sphere: Politics of Commemorative Practices in Turkey." In Visualizing Secularism and Religion: Egypt, Lebanon, Turkey, India. Edited by Alev Çınar, Srirupa Roy, and Maha Yahya. Ann Arbor: The University of Michigan Press, 2012. 93-109. 